\title{
SPREAD SPECTRUM TECHNOLOGY RESEARCH AND ITS APPLICATION IN POWER LINE COMMUNICATION SYSTEMS
}

Edgar M. Dmitriyev,

Tomsk State University of Control Systems

and Radioelectronics (TUSUR), Tomsk, Russia,dmitriyev.edgar@gmail.com

Eugeny V. Rogozhnikov,

Tomsk State University of Control Systems

and Radioelectronics (TUSUR), Tomsk, Russia, udzhon@mail.ru

Andrey K. Movchan,

Tomsk State University of Control Systems

and Radioelectronics (TUSUR), Tomsk, Russia, mr.movchann@mail.ru

Semyon M. Mukhamadiev,

Tomsk State University of Control Systems

and Radioelectronics (TUSUR), Tomsk, Russia, sema.fandmc3@mail.ru

Yakov V. Krukov,

Tomsk State University of Control Systems

and Radioelectronics (TUSUR), Tomsk, Russia, kryukov.tusur@gmail.com

Natalia V. Duplishcheva,

Joint Stock Company "Scientific Research Firm"Micran", Tomsk, Russia,

duplishcheva.nv@micran.ru
DOI: $10.36724 / 2072-8735-2020-\mid 4-10-45-52$

Manuscript received 10 July 2020;

Revised 21 September 2020;

Accepted 28 September 2020

\begin{abstract}
In the presented article, the results of the research of the spreading spectrum technology are given and its use in communication systems based on the data transmission over power lines is considered. One of the currently existing problems of data transmission systems over power lines is the absence of a compromise solution in ensuring the required data transmission rate and communication range. Ready-made solutions existing on the market provide either high data transmission rates over short distances or a communication long-range with rates not exceeding several tens of kilobits per second. The purpose of the article is to research the application of spread spectrum technology in data transmission systems over power lines. In the course of the experiment, it was found that the joint use of OFDM technology and the spread spectrum technology makes it possible to form a solution that provides communication over power lines over a distance of tens of meters with a data transmission rate of at least 5 Mbps. This article compares the TP-Link 500 Mbps modem for broadband high-speed data transmission, and the NWEPLC-I-G3M modem for narrowband low-speed data transmission. The results of modeling a communication system with different lengths and types of spreading sequences for BPSK and QPSK modulations are presented. An assessment of the interference protection was carried out. The results of an experimental research of the spectrum spreading technology on a model of a data transmission system over power lines in terms of range and transmission rate in comparison with existing devices on the market are presented. The results obtained can be used in the design of communication systems over power lines.
\end{abstract}

Information about authors:

Edgar M. Dmitriyev, Assistant, Tomsk State University of Control Systems and Radioelectronics (TUSUR), Tomsk, Russia

Eugeny V. Rogozhnikov, Candidate of Technical Sciences, Docent, Tomsk State University of Control Systems and Radioelectronics (TUSUR), Tomsk, Russia Andrey K. Movchan, Junior Research Associate, Tomsk State University of Control Systems and Radioelectronics (TUSUR), Tomsk, Russia

Semyon M. Mukhamadiev, student of Tomsk State University of Control Systems and Radioelectronics (TUSUR), Tomsk, Russia

Yakov V. Krukov, Candidate of Technical Sciences, Docent, Tomsk State University of Control Systems and Radioelectronics (TUSUR), Tomsk, Russia

Natalia V. Duplishcheva, Engineer-Constructor, Joint Stock Company "Scientific Research Firm"Micran", Tomsk, Russia

Для цитирования:

Дмитриев Э.М., Рогожников Е.В., Мовчан А.К., Мухамадиев С.М., Крюков Я. В., Дуплищева Н.В. Исследование технологии расиирения спектра и её применение в системах передачи данных по цепям электропитания // Т-Сomm: Телекоммуникации и транспорт. 2020. Том 14. № 10. С. 45-52.

For citation:

Dmitriyev E.M., Rogozhnikov E.V., Movchan A.K., Mukhamadiev S.M., Krukov Y.V., Duplishcheva N.V. (2020) Spread spectrum technology research and its application in power line communication systems. T-Comm, vol. I4, no.10, pp. 45-52. (in Russian) 


\section{Introduction}

Every year, more and more new developments in the field of telecommunication technologies become an integral part of the life of every person. The growing demand for broadband communications requires the development of new technologies. Today, "radio frequency" has become a resource that has either to be paid a heavy price or to use license-free frequency bands, which, in most cases, are narrow-band. On the territory of the Russian Federation, unlicensed use is permitted in two ranges, such as PMR (Personal Mobile Radio) and LPD (Lower Power Device) [1].

In addition, it is not always possible to organize communication via wireless communication systems. For example, the design of internal communication systems in spacecraft, ships, and aircraft is subject to strict requirements for electromagnetic compatibility. As a result, the possibility of using additional wireless communication systems is excluded. One possible solution to the problem of unwanted radio emission in this case is the use of data transmission technology over power lines (Power Line Communication, PLC). Another advantage of using this technology is no need to lay additional wire communication lines. In turn, this makes it possible to lighten the design of ships, reduce the cost and reduce technical operating costs, which is most relevant for the space industry.

Currently, PLC technology has found its application in several areas of human activity. One of the applications of PLC technology is monitoring and control in power grids. This field of application is aimed at solving such problems as: remote reading of electricity meters, remote control of electrical equipment at substations, etc. Another application is to organize a high-speed Internet connection at home, in industrial facilities and office buildings. The main advantages of this technology are the availability of infrastructure, easy scalability of the power line and no need for additional cable connections in the room.

Data transmission systems over power lines are divided into two main groups: narrow-band (Narrowband over Power Lines) and wide-band (Broadband over Power Lines) [2].

Narrowband PLC systems are focused on low-speed data transmission and are used in power lines that do not require large amounts of transmitted information. Narrowband PLC systems are used in home automation, in the control of simple household appliances, in industrial automation, in the monitoring and control of energy networks. The data transmission rate in the systems of this group is from 0.1 to $100 \mathrm{Kbps}$ [3].

Broadband PLC systems are focused on high-speed data transmission, are used in the creation of home and office networks that serve to organize high-speed Internet connections, broadcast streaming video, video conferencing and video surveillance systems, digital telephony. The data transmission rate in the systems of this group is from 1 to $200 \mathrm{Mbps}$ [4]. In this case, PLC technology can be considered as an alternative to broadband wireless technologies such as Wi-Fi.

Currently, there are two main standards in the PLC technology (HomePlug AV2 for broadband data transmission systems and G3 PLC for narrowband data transmission systems). The G3 PLC standard provides data transmission over long distances, but at a low transmission rate (up to $50 \mathrm{kbps}$ ) [5, 6], while the HomePlug standard provides hundreds of megabits per second, but the range of the system is much shorter than G3 PLC stand- ard in real conditions. The transmission rate and range characteristics provided by these standards limit their application, since such communication systems either provide too low data transmission rates or operate over a very limited distance. At the moment, there is no intermediate solution on the market that provides communication over a distance of tens of meters, and at the same time provides a data transmission rate sufficient for broadcasting streaming video and exchanging large flows of information (at least $5 \mathrm{Mbps}$ ).

Most of the PLC standards use orthogonal frequencydivision multiplexing (OFDM) technology. The use of this technology in conjunction with the spreading spectrum technology makes it possible to get form a solution that provides communication over power lines at a distance of tens of meters and a data transmission rate of at least $5 \mathrm{Mbps}$. This article demonstrates the possibility of using spread spectrum technology in data transmission systems over power lines.

\section{Description of the data transmission channel on the power lines}

As stated earlier, two-wire power transmission lines used in household power supply systems are used as the physical medium for signal propagation in the PLC channel. Such power lines are an unfavorable medium due to active interference and frequency selective distortion. The presence of a large number of devices connected to the power line has a negative effect on the reliability of a connection. In addition, the characteristics of such systems are highly dependent on the quality of the power line realization in the room and the building as a whole.

When considering the transmission of signals at high frequencies (above $1 \mathrm{MHz}$ ), the power lines are distributedconstant lines. As a medium for signal propagation, its main characteristic is characteristic impedance [7].

Characteristic impedance for two-wire signal propagation lines is calculated by the formula (1).

$$
Z=\frac{120}{\sqrt{\varepsilon}} \ln \frac{2 D}{d},
$$

where $\varepsilon$ - is the dielectric constant of the medium or material where the conductors are located; $D-$ is the distance between the conductors; $d$ - is the diameter of the conductors.

As stated earlier, the PLC channel is an unfavorable medium for signal propagation. A complex interference situation is observed in the channel. Interference is generated by most of the connected electrical devices to the mains. During signal propagation, the power of a signal decreases depending on the distance between the receiver and transmitter and the carrier frequency of the transmission.

Multipath in the communication channel occurs due to the passage of one signal through different paths and reflections from different loads due to mismatch. Multiple rays of the same signal arrive at the receiver with different delays and power levels. As a result, the signals come either in phase or in antiphase. This leads to a significant decrease in the total signal level on the receiving side, which it impossible to carry out error-free signal processing. This effect is called signal fading.

The multipath parameters in the PLC channel are directly dependent on the physical topology of the network. 


\section{Power transmission technology}

As noted above, most devices to provide data transmission via power lines are based on two main communication standards: standard G3 PLC for narrowband modems and standard HomePlug AV2 for broadband [5, 6]. These standards have a similar physical layer structure and use similar algorithms to generate the signal. In addition to these standards, we considered other standards PLC technology. For example, PRIME, LonWorks, KNX, etc. The Figure 1 shows a common block diagram of the transmitter based on the algorithms described in considered standards. Block diagram of the transmitter includes the following blocks: scrambler, encoder, interleaver, mapper, IFFT block, cyclic prefix adding block, frame-forming block.

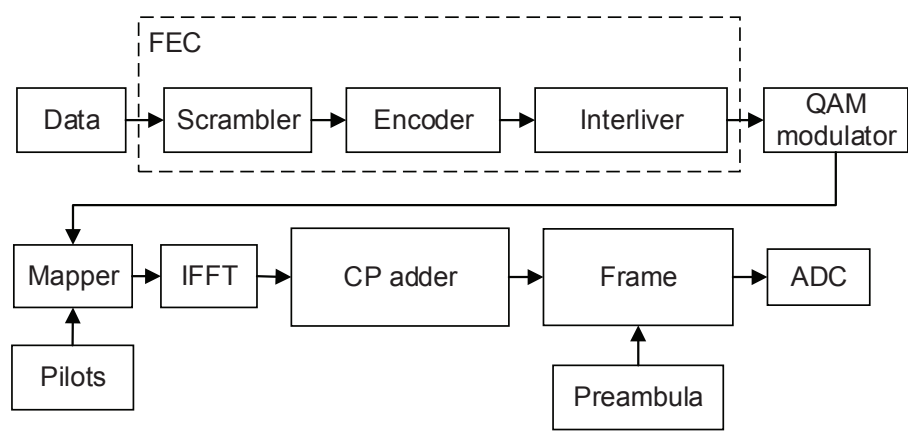

Figure 1 Common block diagram of the PLC transmitter

At the physical layer, the information bit stream comes at the scrambler block. Scrambling the data provides a random distribution of the transmitted information. It allows equalize the energy spectrum of the signal and reduce the peak factor (ratio of maximum signal power to average) [11].

As mentioned earlier, the complex interference situation in the power line, caused by impulse interference from connected devices, multipath propagation and strong attenuation affect the high requirements for system noise immunity. Therefore, most standards use cascading coding methods with great redundancy. In G3 standard used cascading coding. This coding includes the Reed-Solomon (RS) encoder and a convolutional encoder $(171,133)$ [6]. In broadband communication, standards (Homeplug AV), in addition to Reed-Solomon and convolutional codes (CC), turbo codes and low-density parity-check code (LDPC) are used [10].
To deal with packet errors, the subsequent bit stream is interleaved. That is, in the packet, the bits of the encoded information are distributed according to a pseudo-random law. On the receiving side, the reverse operation is carried out according to the same pseudo-random law.

In the modulator, the digital stream is converted into a modulated data stream by means of well-known types of quadrature modulation. Low-speed standards (G3 PLC, etc.) support data transmission using BPSK, QPSK, DPSK and D8PSK [6]. Some wideband standards use QAM modulation with an index from 1 to 1024 , which allows transmission of 1 to 10 bits per modulation symbol [10].

Common to most PLC standards is the use of OFDM technology. This technology is used in many wireless standards: LTE, WiMAX, Wi-Fi, etc. OFDM has a number of advantages that have made it possible to transmit data over power lines. Firstly, OFDM modulation has high spectral efficiency. Channels called subcarriers in OFDM modulation arranged orthogonally to each other. Therefore, in OFDM modulation, the subcarriers can be located closer than in the case of BPSK, QPSK, MQAM without OFDM. For the lack of the Doppler Effect in the wire channel, subcarriers can arrange much closer to each other in comparison with the radio channel. Secondly, the long duration of the OFDM symbol using a guard interval in the time domain (cyclic prefix) provides good protection against symbol interference and fading resulting from multipath propagation. The structures for generating OFDM symbols are different for each standard. The number of subcarriers ranges from 68 per symbol (G3) to 4096 per symbol (Homeplug, IEEE 1901.1) [10]. Signal forming is implemented in the frequency domain. Therefore, the inverse fast Fourier transform is used to transference from the frequency domain to the time domain. This introduces some restrictions. Therefore, the size of the Fourier transform must be a multiple of the power of two. However, it also allows simplifies the calculation procedure, because of the properties of the fast Fourier transformation.

In the time domain, a cyclic prefix is added. In PLC systems, the cyclic prefix size ranges from $1 / 16$ to $1 / 2$ of the total symbol duration. Cyclic prefix large size is used in protected modes. The large size of the cyclic prefix used to protect against reflected signals from the far ends of the power lines. The main characteristics of the PLC communication standards are given in Table 1 $[5,6,8-10]$.

Characteristics of Standards

\begin{tabular}{|l|l|l|l|l|}
\hline \multicolumn{1}{|c|}{ Standard } & \multicolumn{1}{|c|}{ Frequency range } & \multicolumn{1}{c|}{ Modulation } & \multicolumn{1}{c|}{ FEC } & \multicolumn{1}{c|}{ Transmission rate } \\
\hline G3 & $35-91 \mathrm{kHz}$ & OFDM (DQPSK, DBPSK) & RS, RC, CC & $5.6-45 \mathrm{kbps}$ \\
\hline PRIME & $4 \quad \mathrm{kHz}$ & $\begin{array}{l}\text { OFDM (D8PSK, DPSK, } \\
\text { DQPSK) }\end{array}$ & CC & $21.4-128 \mathrm{kbps}$ \\
\hline Homeplug AV2 & $2-86 \mathrm{MHz}$ & OFDM (QPSK) & Turbo CC, & $100-200 \mathrm{Mbps}$ \\
\hline X-10 & $120 \mathrm{kHz}$ & On Off Keying & - & $24-120 \mathrm{bps}$ \\
\hline LonWorks & $120-140 \mathrm{kHz}$ & BPSK/NRZ & - & $3.6-5.4 \mathrm{kbps}$ \\
\hline KNX & $125-140 \mathrm{kHz}$ & S-FSK/NRZ & - & $1200 \mathrm{bps}$ \\
\hline G.hn & $80-100 \mathrm{MHz}$ & OFDM (1-4096 QAM) & CC, RS & $1-56 \mathrm{Mbps}$ \\
\hline IEEE 1901.1 & $2-12 \mathrm{MHz}$ & OFDM & RS, turbo CC, LDPC & $<100 \mathrm{Mbps}$ \\
\hline
\end{tabular}




\section{Description of spreading spectrum technology}

Power lines are an unfavorable environment, a source of active interference, the cause of frequency-selective distortion. The large number of devices connected to the power line negatively affects the reliability of communication. Also, the characteristics of such systems depend heavily on the quality of network performance in the room and the building.

This section describes the encoding method in spread spectrum communication systems to increase the interference protection of the system. This method allows the use of a few subcarriers for transmitting one bit of information. It increasing the energy spent on transmitting one bit. The block diagram of the approach under consideration is shown in Figure 2.

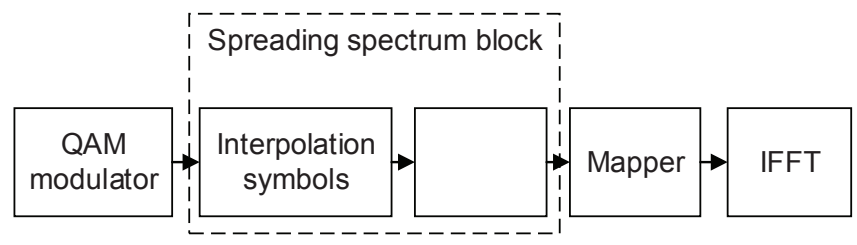

Figure 2 Block diagram of the spreading spectrum block

In fact, the method under consideration is an MC-CDMA technology [12], for one user. This technology uses orthogonal codes. These codes are sets of sequences with the crosscorrelation of any two combinations taken separately where correlation is zero [12]. There are many types of orthogonal codes: Walsh codes, Barker codes, M-sequences, etc.

When choosing a code sequence to extend the spectrum in this case, the determining factor is the length of the sequence, because it provides the higher energy in the receiver.

The autocorrelation properties of the code combination do not have an important role, because the temporal synchronization on these sequences in the method under consideration is not performed. We do not use orthogonal codes for synchronization purposes. This is confirmed by the simulation results. In the case of multi-user mode, the code sequences used should be orthogonal.

On the transmitting side, when encoding, the input stream of modulation symbols after the modulator is multiplied with the code sequence (2).

$$
Y(i \times N)=[\text { Walsh }(N) \times A(i)],(2)
$$

where $Y(i)$ - coded modulation symbols; Walsh $(N)$ - a coding sequence of length $N ; A(i)$ - modulation symbols.

As a result, the input symbol of the modulation is aligned with the sequence of symbols.

On the receiving side, correlation processing of the received modulation symbols is implemented in the frequency domain (3).

$$
X(i)=\frac{F^{-1}\left(F\left(Y^{\prime}(i \times N)\right) \times F(\operatorname{Walsh}(N))^{*}\right)}{N},
$$

where $X(i)$ - decoded modulation symbols; $\mathrm{F}^{-1}$ - Inverse Fourier Transform; $F$ - Fourier Transform.

Figure 3 shows a block diagram of a correlation receiver performing demodulation on the receiving side.

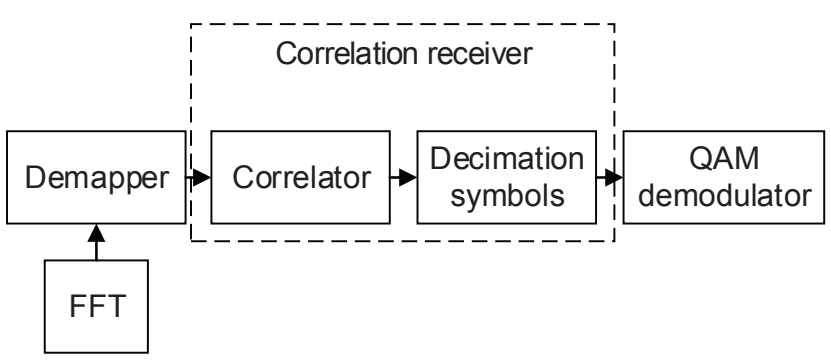

Figure 3 Block diagram of the correlation receiver

\section{Simulation of Spreading Spectrum Technology with Different Lengths of a Coding Sequence}

The simulation of the communication system for determining the efficiency of using the spreading spectrum technology was carried out in the MATLAB software package. The initial objective was to determine the type of coding sequence and its length.

Figure 4 presents a structural diagram of the simulation.

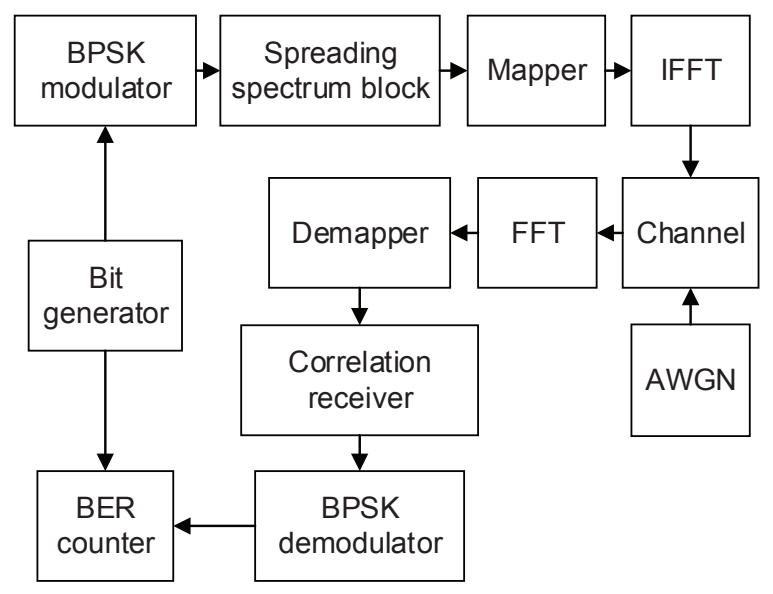

Figure 4 Block diagram of the simulation

A channel with additive white Gaussian noise is the most common channel model used in the calculating and modeling of information transmission systems. This type of noise is characterized by a uniform spectral power density in the range of all frequencies, a normal distribution and an addition action, that is, summation with a useful signal [13].

The main characteristics of signal formation during modeling are shown in Table 2

Table 2

Signal characteristics

\begin{tabular}{|l|l|}
\hline \multicolumn{1}{|c|}{ Parameter } & \multicolumn{1}{c|}{ Value } \\
\hline Size of the Fourier transform & 1024 \\
\hline Cyclic prefix size & $1 / 32 \mathrm{smpl}$. \\
\hline Number of information subcarriers & 823 \\
\hline Guard interval & $200 \mathrm{smpl} .(10 \%)$ \\
\hline
\end{tabular}
bol.

Figure 5 shows the spectrum of the generated OFDM sym- 


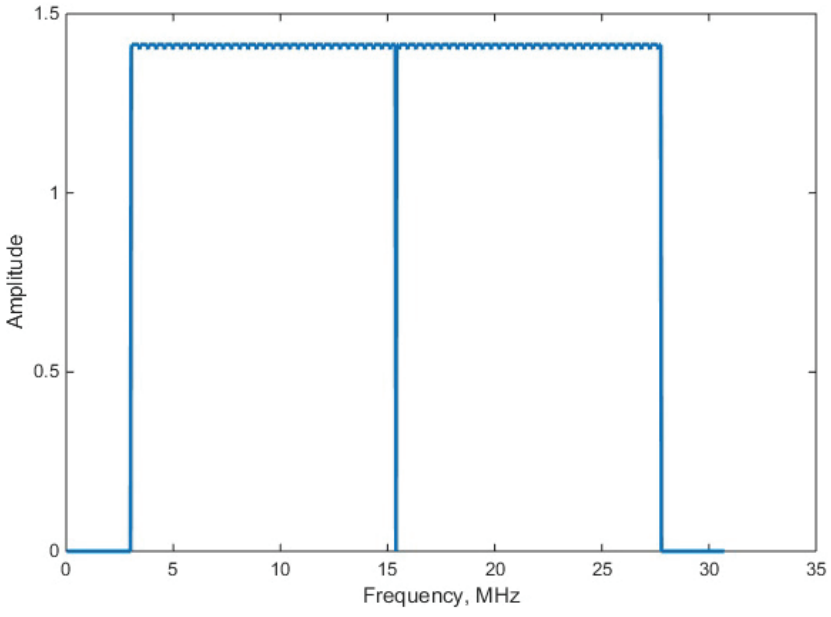

Figure 5 Spectrum OFDM symbol

During the simulation, various types of orthogonal codes with different autocorrelation properties were checked. Table 3 shows the source data for modeling coding.

Table 3

Initial Data

\begin{tabular}{|c|c|c|}
\hline $\begin{array}{c}\text { Code } \\
\text { length }\end{array}$ & Type of Modulation & Type of code \\
\hline 2 & BPSK, QPSK & Walsh 2 (1-1) \\
\hline \multirow{2}{*}{4} & BPSK & Walsh 4 (1-1-11) \\
& & Barker 4 (111-1) \\
& & PRBS 4 (1-11) \\
\cline { 2 - 3 } & QPSK & Walsh 4 (1-1-11) \\
\hline 8 & BPSK, QPSK & Walsh 8 (1-1-111-1-1) \\
\hline
\end{tabular}

Figure 6, Figure 7 and Figure 8 present the simulation results.

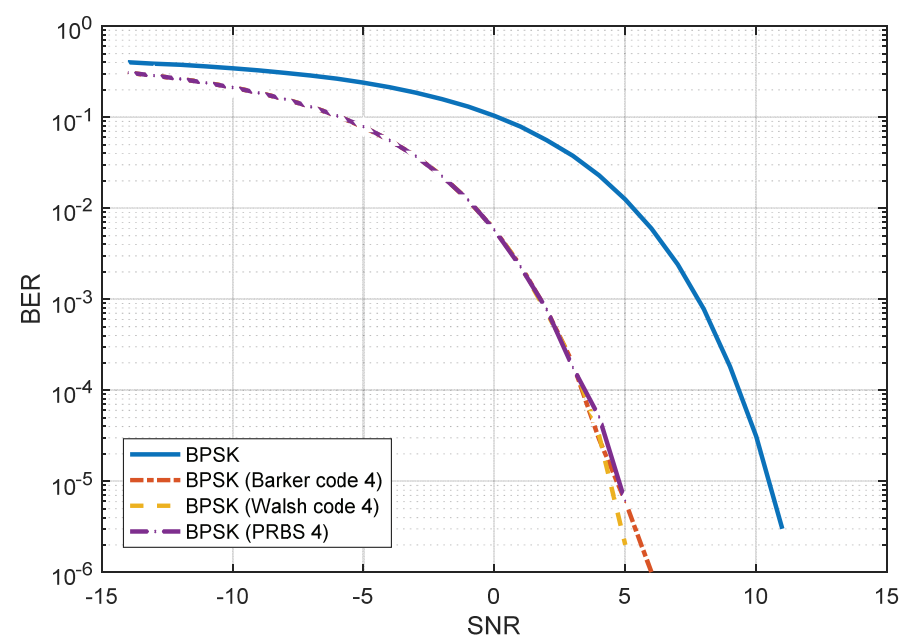

Figure 6 BPSK with different types of code sequence with a length of 4

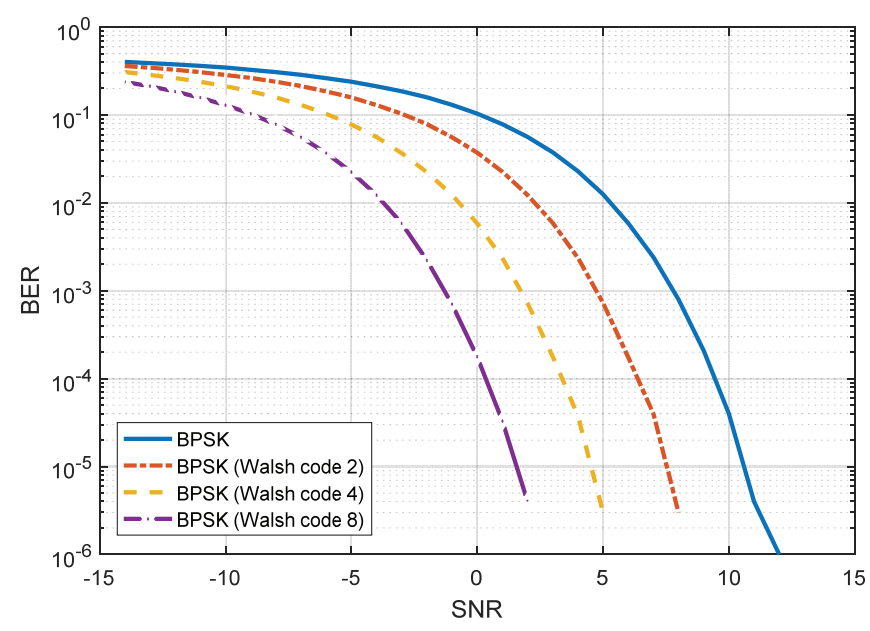

Figure 7 BPSK with different lengths of Walsh code sequence

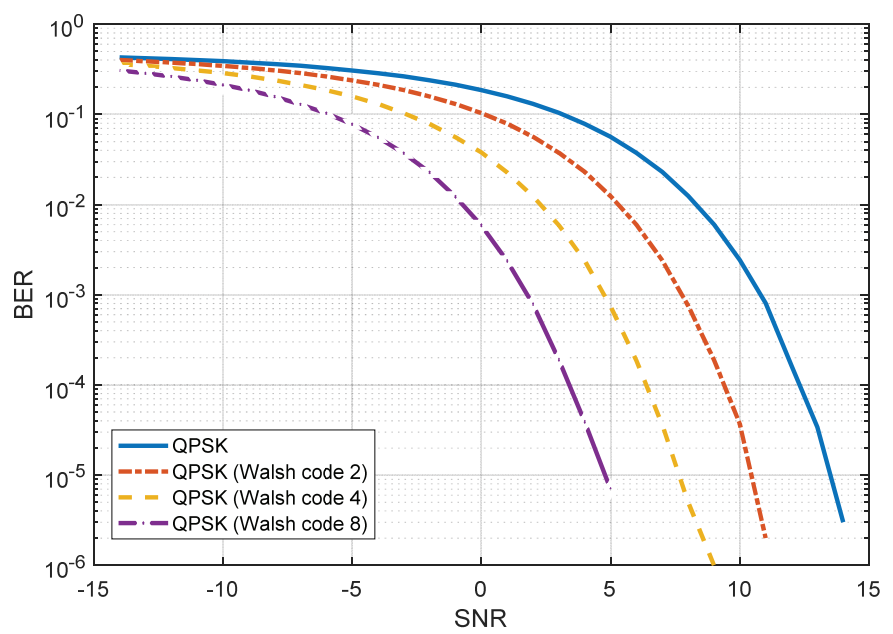

Figure 8 QPSKs with different Walsh code sequence lengths

After analyzing of the graphs presented in Figure 6-8, we can conclude that the use of various codes does not affect the interference protection of the system. The reason for this is that we only use the maxim correlation value. The correlation peak depends on the length of the coding sequence, but does not depend on the type of sequence. As a result, the Walsh, Barker, and Msequence codes of the same lengths gave the same result. Only the length of the codes used affected the interference protection of the system.

In connection with the presented modeling in an experimental study, it was decided to use BPSK modulation with spreading of the spectrum using a Walsh code with a length of 4 .

\section{Comparison of homeplug and G3PLC PLC Modems with a Modem Using Spread Spectrum Technology in Terms of Speed and Transmission Distance}

For the experiment, we purchased the TP-Link $500 \mathrm{Mbps}$ modem, for broadband high-speed data transmission, and the NWEPLC-1-G3M, for narrowband low-speed data transmission.

We carried out the experiment at the university, where lecture rooms, computer rooms, laboratories were located. 


\section{ELECTRONICS. RADIO ENGINEERING}

The map of the experiment is shown in Figure 9. For the experiment, the working time was chosen in order to provide a real possible load on the power lines.

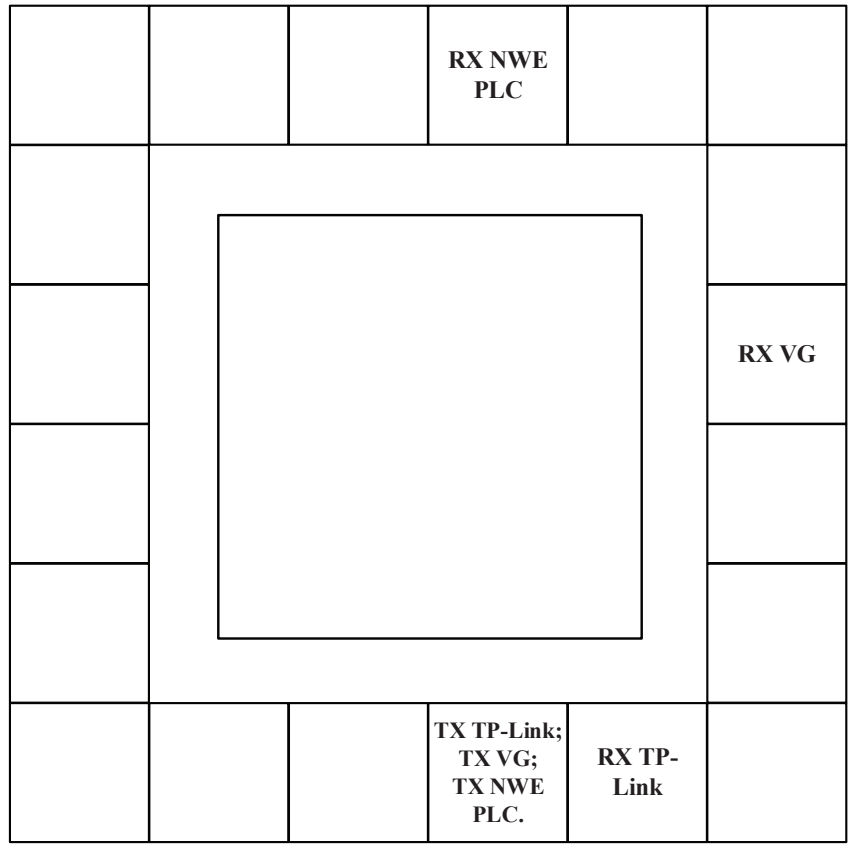

Figure 9 Map of the experiment

First, we tested the range of already ready commercial modem solutions: TP-Link.

The experiment was carried out according to the schema presented in Figure 10.

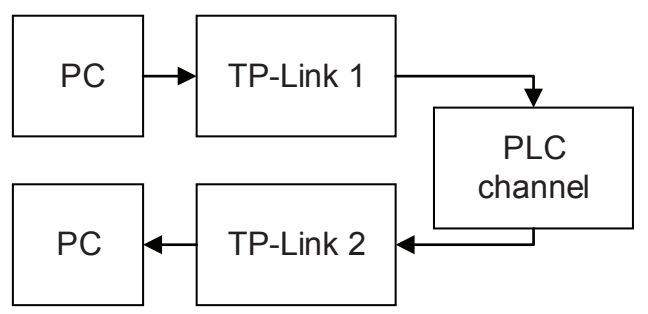

Figure 10 Scheme of the TP-Link modems communication range experiment

A connection between two points was detected when two devices were connected through a PLC channel. The transmission rate was measured using the Iperf program.

Table 4 presents the results for the maximum range and transmission rate for each of the modems.

Table 4

Experiment Results

\begin{tabular}{|l|c|c|c|c|}
\hline \multirow{2}{*}{ Modem } & \multicolumn{2}{|c|}{$\begin{array}{c}\text { Maximum Communication } \\
\text { Range }\end{array}$} & \multicolumn{2}{c|}{$\begin{array}{c}\text { Maximum } \\
\text { transmission }\end{array}$} \\
\cline { 2 - 5 } & Rate, Mbps & Distance, $\mathrm{m}$ & Rate, Mbps & Distance, $\mathrm{m}$ \\
\hline TP-Link & 11 & 12 & $34-56$ & $2-4$ \\
\hline NWEPLC & 0,023 & 56 & 0,046 & $2-35$ \\
\hline Stand & & 36 & 21 & $2-4$ \\
\hline
\end{tabular}

In the course of the experiment, data was transmitted in one direction. In this case, the position of the transmitting devices during the experiment was unchanged, in Figure 9 it is denoted "TX". "RX" is the receiving devices, where the establishment of the connection between the devices was recorded using a personal computer.

The maximum transmission range for TP-Link modems was $12 \mathrm{~m}$. The actual communication range has been taken into account, but not the line length. From this, we can conclude that modern PLC modems are a good option for solving the problem of organizing high-speed communications in one room, at home. But if there is a need for organizing communications in office buildings with large areas, in order to provide high-speed Internet throughout the territory, it will be necessary to organize a network with a large number of relay devices. It will affect the cost of the network.

For narrow-band NWEPLC-1 modems, the structure of the experiment repeated the scheme of the previous experiment (Figure 11). The results of the experiment are shown in Table 4.

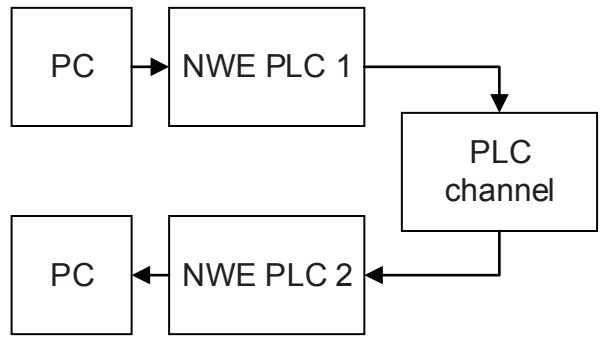

Figure 11 Scheme of the experiment for determining the communication range of NWEPLC-1 modems

As expected, a narrowband PLC modem allows you to organize communication on the entire floor, but provides lowspeeds even taking into account its maximum possible.

To implement the data transmission through power lines using the technology of spreading the spectrum, a laboratory stand was assembled. The block diagram of the laboratory stand is shown in Figure 12.

As a result, the input symbol of the modulation corresponds to a sequence of characters.

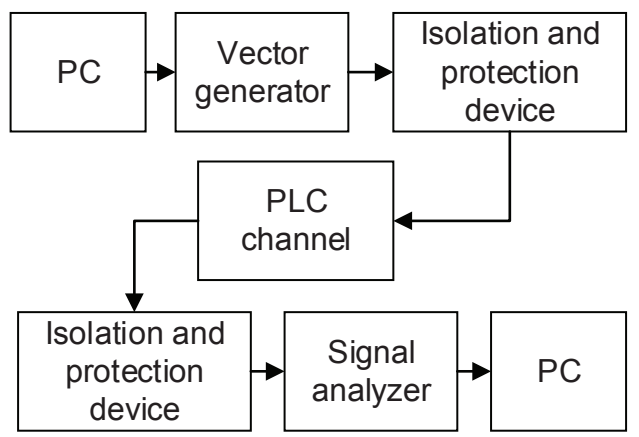

Figure 12 Block diagram of the laboratory stand of the transmission of data on power lines

The stand is transmitting and receiving parts, which include:

- A personal computer, to form a data array, control the communication system algorithm and traffic; 
control;

A vector generator that acts as a signal source and gain

- Isolation and protection device at the receiving and transmitting parts;

- A signal analyzer used as a receiving device;

- A personal computer at the receiving part, which is used to process the received signal.

On the transmitting side, a signal was generated with the parameters presented in Table 5. The transmission received the same signal power as the TP-link modems gave.

Table 5

Signal parameters

\begin{tabular}{|c|c|}
\hline Parameter & Value \\
\hline FFT size & 1024 \\
\hline CP & $1 /$ \\
\hline Band & $\mathrm{MHz}$ \\
\hline Type of Modulation & BPSK \\
\hline Spectrum expansion & Walsh $(4)$ \\
\hline
\end{tabular}

The results of the experiment are presented in Table 4. The prototype of the data transmission via the power lines made it possible to transmit to a maximum distance of 36 meters with a transmission rate of 5.2 Mbps. Within one room, using it, it was possible to organize a connection with a transmission rate of 15-21 Mbps.

\section{Conclusion}

Thus, we can infer that the technology of spreading the spectrum by encoding subcarriers allows for compromise between two commercial solutions of broadband and narrowband communication. This technology made it possible to organize communication at a distance three times greater than that of modems for broadband PLC communications, in particular the TP-link $500 \mathrm{Mbps}$ modem. In terms of communication range in comparison with NWEPLC-1-G3M, the presented model of the data transmission system over power lines significantly inferior, since it belongs to the broadband as a result of which a large signal attenuation in conditions of the same power does not allow achieving the same results in terms of communication distance.

\section{References}

1 Ranges PMR, LPD, FRS, GMRS and KDR [Electronic resource]. Free access mode https://trcvr.ru/2015/08/11/diapazony-pmrlpd-frs-gmrs-i-kdr/ (date accessed: 20.08.2020).

2 Victor Okhrimenko. PLC technology. Part 1. Ed. State Research Center of Applied Informatics, Kiev, 2009. Pp.58-62.

3 Victor Okhrimenko. Narrowband PLC technology: OFDM modulation. Ed. Electronic components, 2010. No.9. Pp.42-46.

4 Victor Okhrimenko. Broadband PLC Technologies: Problems and Solutions. Ed. Electronic components, 2010. No.1. Pp.43-49.

5 HomePlug Power Line Alliance, "HomePlug AV baseline specification," Version 1.0.00, Dec. 2005.

6 France E. R. D. G3-PLC physical layer specification //August, http://www. maximintegrated. com/products/powerline/pdfs/G-PLCPhysical-Layer-Specification. pdf. 2009.

7 Movchan A.K., Dmitriev E.M., Rogozhnikov E.V. Circuitry of receiving and transmitting paths of broadband PLC communication systems. Electronic means and control systems. Materials of reports of the International scientific-practical conference. Federal State Budgetary Educational Institution of Higher Education Tomsk State University of Control Systems and Radioelectronics, 2018. No.. 1-2. Pp. 295-298.

8 Hoch M. Comparison of PLC G3 and PRIME. 2011 IEEE International Symposium on Power Line Communications and Its Applications. IEEE, 2011. Pp. 165-169.

9 Yuejun Z., Mingguang W. Design of wireless remote module in $\mathrm{X}-10$ intelligent home. 2005 IEEE International Conference on Industrial Technology. IEEE, 2005. Pp. 1349-1353.

10 Mudriievskyi S., Lehnert R. Performance evaluation of the G. hn PLC PHY layer. 18th IEEE International Symposium on Power Line Communications and Its Applications. IEEE, 2014. Pp. 296-300.

11 Sa'adah N., Astawa I. G. P., Sudarsono A. Trusted Data Transmission Using Data Scrambling Security Method with Asymmetric Key Algorithm for Synchronization. EMITTER International Journal of Engineering Technology. 2018. Vol. 6. No. 2. Pp. 217-235.

12 Hanzo L. et al. OFDM and MC-CDMA for broadband multiuser communications, WLANs and broadcasting. - John Wiley \& Sons, 2005. 977 p.

$13 \mathrm{Li}$ D. Channel capacity on additive white Gaussian noise channel under overlapped multiplexing principle. Journal of Beijing University of Posts and Telecommunications. 2016. Vol. 39. No. 6. Pp. 1-10. 


\title{
ИССЛЕДОВАНИЕ ТЕХНОЛОГИИ РАСШИРЕНИЯ СПЕКТРА И ЕЁ ПРИМЕНЕНИЕ В СИСТЕМАХ ПЕРЕДАЧИ ДАННЫХ ПО ЦЕПЯМ ЭЛЕКТРОПИТАНИЯ
}

\author{
Дмитриев Эдгар Михайлович, Томский государственный университет систем управления и радиоэлектроники (ТУСУР), \\ 2. Томск, Россия, dmitriyev.edgar@gmail.com
}

Рогожников Евгений Васильевич, Томский государственный университет систем управления и радиоэлектроники (ТУСУР), 2. Томск, Россия, udzhon@mail.ru

Мовчан Андрей Кириллович, Томский государственный университет систем управления и радиоэлектроники (ТУСУР), г. Томск, Россия, mr.movchann@mail.ru

Мухамадиев Семен Минисович, Томский государственный университет систем управления и радиоэлектроники (ТУСУР), 2. Томск, Россия, sema.fandmc3@mail.ru

Крюков Яков Владимирович, Томский государственный университет систем управления и радиоэлектроники (ТУСУР), 2. Томск, Россия, kryukov.tusur@gmail.com

Дуплищева Наталья Витальевна, АО "НПФ"МИКРАН", г. Томск, Россия, duplishcheva.nv@micran.ru

\section{Аннотация}

Приведены результаты исследования технологии расширения спектра и рассмотрена возможность её использования в системах связи, основанных на передаче данных по цепям электропитания. Одна из имеющихся на данный момент проблем систем передачи данных по цепям электропитания заключается в отсутствии решения-компромисса в обеспечении необходимой скорости передачи данных и дальности связи, так как существующие на рынке готовые решения обеспечивают либо высокую скорость передачи данных на небольших расстояниях, либо хорошую дальность связи, но со скоростями, не превышающими несколько десятков килобит в секунду. Цель работы заключается в исследовании применения технологии расширения спектра в системах передачи данных по цепям электропитания. В ходе эксперимента было установлено, что совместное использование технологии OFDM с технологией расширения спектра позволяет сформировать решение, обеспечивающее связь по цепям электропитания на расстояние в десятки метров со скоростью передачи данных не менее 5 Мбит/с. Приведены результаты сравнения модемов TP-Link 500 Mbps, для широкополосной высокоскоростной передачи данных, и NWEPLC-I-G3M, для узкополосной низкоскоростной передачи данных. Представлены результаты моделирования системы связи с различной длиной и типами расширяющих последовательностей для модуляций BPSK и QPSK. Проведена оценка помехозащищенности. Приведены результаты экспериментального исследования технологии расширения спектра на макете системы передачи данных по цепям электропитания с точки зрения дальности и скорости передачи по сравнению с существующими устройствами на рынке. Полученные результаты могут быть использованы при проектировании систем связи по линиям электропередачи.

Ключевые слова: линия электропитания, OFDM, расширение спектра, PLC канал, передатчик, стандарты связи, модем TP-Link 500 Mbps, модем NWEPLC-I-G3M.

\section{Литература}

I. Диапазоны PMR, LPD, FRS, GMRS и KDR [Электронный ресурс]. Режим доступа свободный https://trcvr.ru/2015/08/I I/diapazony-pmr-Ipd-frsgmrs-i-kdr/ (дата обращения: 20.08.2020).

2. Виктор Охрименко. PLC-технологии. Часть І. Изд. Государственный НИЦ прикладной информатики, Киев, 2009. С. 58-62.

3. Виктор Охрименко. Узкополосная PLC-технологии: OFDМ-модуляция. Изд. Электронные компоненты, 2010. №9. С. 42-46.

4. Виктор Охрименко. Широкополосная PLC-технологии: Проблемы и решения. Изд. Электронные компоненты, 20I0. №I. С. 43-49.

5. HomePlug PowerLine Alliance, "HomePlug AV baseline specification," Version I.0.00, Dec. 2005.

6. France E. R. D. G3-PLC physical layer specification // August, http://www. maximintegrated. com/products/powerline/pdfs/G-PLC-Physical-LayerSpecification. pdf. 2009.

7. Мовчан А. К., Дмитриев Э. М., Рогожников Е. В. Схемотехника приемно-передающих трактов широкополосных PLC-систем связи //Электронные средства и системы управления. Материалы докладов Международной научно-практической конференции. - федеральное государственное бюджетное образовательное учреждение высшего образования Томский государственный университет систем управления и радиоэлектроники, 2018. №. I-2. C. 295-298.

8. Hoch M. Comparison of PLC G3 and PRIME // 201 I IEEE International Symposium on Power Line Communications and Its Applications. IEEE, 20II. Pp. 165-169.

9. Yuejun Z., Mingguang W. Design of wireless remote module in X-10 intelligent home // 2005 IEEE International Conference on Industrial Technology. IEEE, 2005. Pp. I349-I353.

10. Mudriievskyi S., Lehnert R. Performance evaluation of the G. hn PLC PHY layer // I8th IEEE International Symposium on Power Line Communications and Its Applications. IEEE, 2014. Pp. 296-300.

II. Sa'adah N., Astawa I. G. P., Sudarsono A. Trusted Data Transmission Using Data Scrambling Security Method with Asymmetric Key Algorithm for Synchronization //EMITTER International Journal of Engineering Technology. 20I8. T. 6. №. 2. C. 217-235.

12. Hanzo L. et al. OFDM and MC-CDMA for broadband multi-user communications, WLANs and broadcasting. John Wiley \& Sons, 2005.977 p.

13. Li D. Channel capacity on additive white Gaussian noise channel under overlapped multiplexing principle // Journal of Beijing University of Posts and Telecommunications. 2016. T. 39. №. 6. C. I-10.

Информация об авторах:

Дмитриев Эдгар Михайлович, ассистент Томского государственного университета систем управления и радиоэлектроники (ТУСуР), г. Томск, Россия Рогожников Евгений Васильевич, к.т.н., доцент Томского государственного университета систем управления и радиоэлектроники (ТУСуР), г. Томск, Россия Мовчан Андрей Кириллович, младший научный сотрудник Томского государственного университета систем управления и радиоэлектроники (ТУСуР), г. Томск, Россия Мухамадиев Семен Минисович, студент Томского государственного университета систем управления и радиоэлектроники (ТУСуР), г. Томск, Россия Крюков Яков Владимирович, к.т.н., доцент Томского государственного университета систем управления и радиоэлектроники (ТУСуР), г. Томск, Россия Дуплищева Наталья Витальевна, инженер-конструктор, АО "НПФ"МИКРАН", г. Томск, Россия 